\title{
THE LATE DEVONIAN UPPER KELLWASSER EVENT IN THE DEEP-WATER DEPOSITS OF THE WESTERN SLOPE OF THE SUBPOLAR URALS [KOZHYM RIVER SECTION)*
}

\author{
M. A. Soboleva, D. B. Sobolev \\ Institute of Geology FRC Komi SC UB RAS, Syktyvkar; matusha.888@mail.ru, dbsobolev@rambler.ru
}

\begin{abstract}
The Upper Kellwasser Event is recognized for the first time in the deep-water succession of the Kozhym River section on the Western slope of the Subpolar Urals, based on conodont biostratigraphy, lithological changes and positive shifts of the carbon isotope value $\left(\delta^{13} \mathrm{C}\right)$ across the Frasnian-Famennian (F-F) boundary interval. Conodonts are abundant in the Frasnian Upper rhenana Subzone, but show a low diversity at the level of transgressive Upper Kellwasser Event in the linguiformis Zone, and are almost absent in the Famennian subperlobata Zone. Black shale horizons associated with the global Upper Kellwasser Event were identified in the linguiformis Zone in the Kozhym River section. Positive shifts in the carbon isotope ratio during the linguiformis Zone to the Lower triangularis Subzone (lower part) are observed, similar to those reported from elsewhere around the world (positive $\delta^{13} C_{\text {carb }}$ shifts $\sim$ from 3 to $4 \%$ ). The data obtained allow the black shales associated with the Upper Kellwasser Event and carbon isotope fluctuations to be precisely dated and correlated.
\end{abstract}

Keywords: conodonts, Upper Kellwasser Event, Frasnian-Famennian boundary, Subpolar Urals, Kozhym River section.

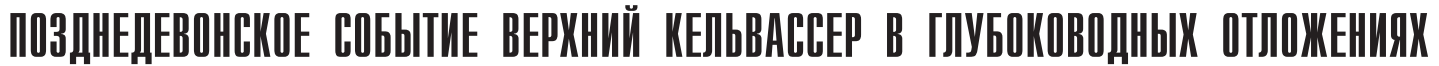 ЗАПАДНОГО СКЛОНА ПРИПОЛЯРНОГО УРАЛА (РАЗРЕЗ ПО Р. КОЖЫМ)}

\author{
М. А. Соболева, Д. Б. Соболев \\ Институт геологии ФИЦ Коми НЦ УрО РАН, Сыктывкар
}

На основании конодонтовой биостратиграфии, литологических изменений, а также положительных сдвигов значения изотопов углерода $\left(\delta^{13} \mathrm{C}\right)$ на пограничном франско-фаменском интервале в разрезе р. Кожым западного склона Приполярного Урала впервые обнаружено событие Верхний Кельвассер. Конодонты в изобилии присутствуют в интервале верхней подзоны rhenana во фране, но демонстрируют низкое разнообразие на уровне трансгрессивного события Верхний Кельвассер в зоне linguiformis и практически отсутствуют в интервале зоны subperlobala в фамене. В разрезе р. Кожым в зоне linguiformis выявлены горизонты черного сланца, связанные с событием Верхний Кельвассер, и наблюдаются положительные сдвиги значения изотопов углерода в интервале зон linguiformis - Lower triangularis (нижняя часть), аналогичные тем, о которых сообщалось в работах различных стран мира (положительный $\delta^{13} C_{\text {carb }}$ сдвиг 3-4 \%о). Полученные данные позволяют точно датировать и коррелировать черные сланцы, связанные с событием Верхний Кельвассер и флуктуациями изотопов углерода.

Ключевые слова: конодонты, событие Верхний Кельвассер, граница франа и фамена, Приполярный Урал, разрез по p. Кожым.

\section{Introduction}

Many studies on the Devonian system [3, 12, 14, 18, 20-21, etc.] deal with the problem of event-stratigraphic levels in the Frasnian (Fig. 1, C). First of all, they concern the boundary deposits of the Frasnian-Famennian (F-F) Upper Kellwasser Event (Fig. 1, C). The Upper Kellwasser Event is a globally widespread synchronous event with anoxic conditions developing in many oceanic settings during the linguiformis conodont Zone to the Lower triangularis conodont Subzone. Interest in that event has particularly increased in recent years, as an integrated approach to the study of biostratigraphy, lithology, and geochemistry has enabled more effective interregional correlations.

In different regions of the world, the Upper Kellwasser Event can be detected as a bioevent, a lithoevent and C-isotope event [3, 5, 12, 14, 20-21, etc.]. The sections of the F-F boundary interval represent different shelf facies zones of the North of Urals. The most complete profile interpreted from these sections is known in the southern part of the Chernyshev Ridge continuing up to the junction zone of the Yelets and Lemva facies zones in the Subpolar Urals. This profile covers the intrashelf depression, the bioherm structures of the shelf edge, the continental slope and its base [18]. This paper focuses on conodont stratigraphy, facies and carbonate carbon isotope study around the Upper Kellwasser Event in the Kozhym River section on the Western slope of the Subpolar Urals (Fig. 1, A, B). This section characterizes the intrashelf depression type of the Yelets facies zone and demonstrates an uninterrupted F-F boundary sequence.

\section{Material and methods}

The F-F boundary interval of the Kozhym River section was studied for biostratigraphy, lithology, and chemostratigraphy.

* Статья опубликована в рамках 9-го научного кафе. См. Весйник № 10, 2019.

The paper is published within the framework of the 9th Science Cafe. See Vestnite No. 10, 2019. 

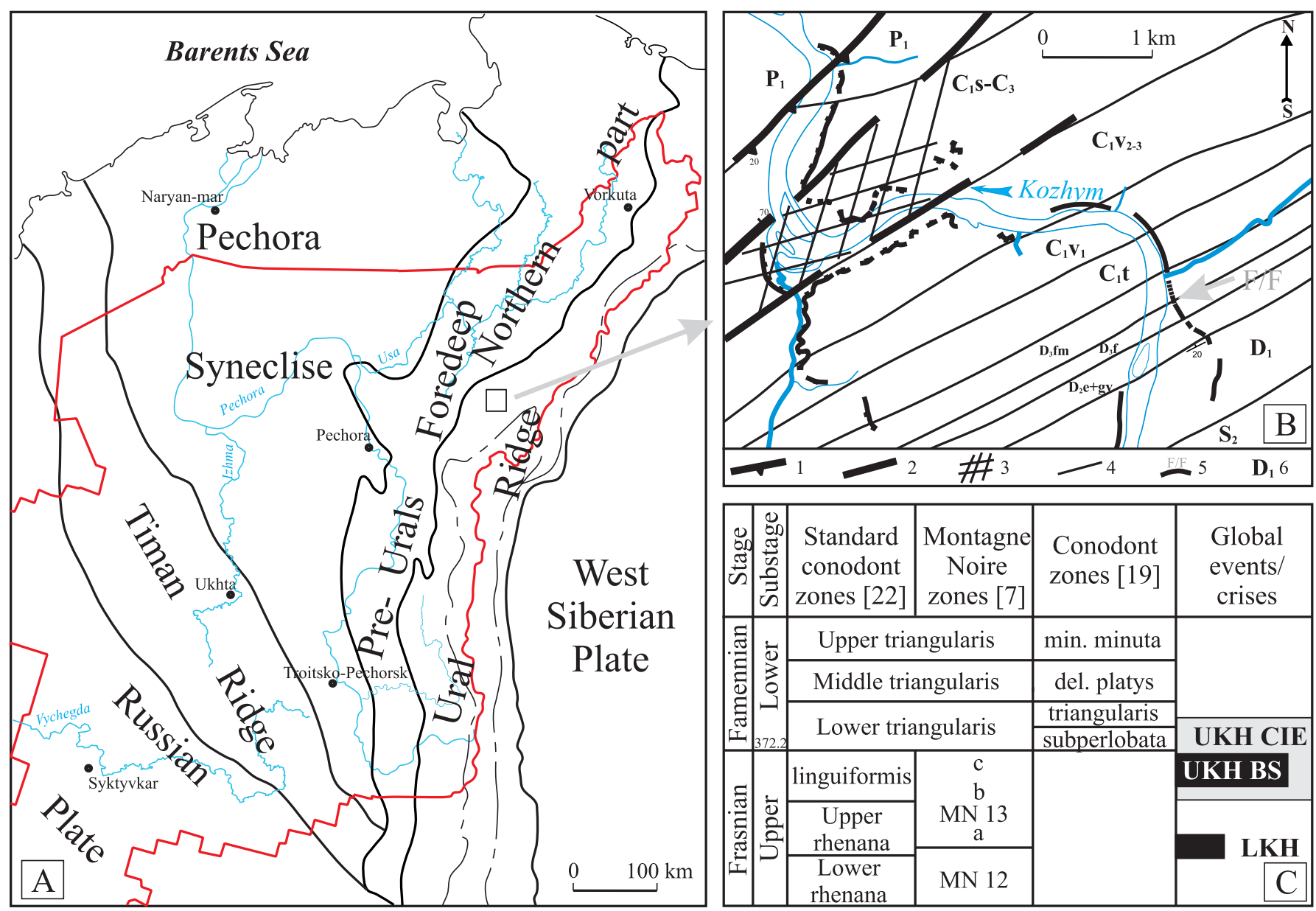

Fig. 1. A - Location of the studied area on the tectonic scheme of the Timan-Pechora Province; B - Locality map of the FrasnianFamennian deposits on the Kozhym River. 1 - Main West Urals Thrust, 2 - sideshift thrusts, 3 - brecciation and recrystallization zones, 4 - stratigraphic boundaries, 5 - outcrops, 6-age. C - Upper Frasnian to Lower Famennian correlation of conodont zones compared with the timing of global events. LKH - Lower Kellwasser Horizon, UKH BS - Upper Kellwasser Horizon, black shales interval, UKH CIE - Upper Kellwasser Horizon, carbon isotope excursion interval

Рис. 1. А - местонахождение района исследований на тектонической схеме Тимано-Печорской провинции; В - расположение франско-фаменских отложений по р. Кожым; 1 - Главный Западноуральский надвиг, 2 - взбросонадвиги, 3 - зона брекчирования и перекристаллизации, 4 - стратиграфические границы, 5 - обнажения, 6 - возраст. С - верхнефранская и нижнефаменская корреляция конодонтовых зон с глобальными событиями. LKH - горизонт Нижний Кельвассер, UKH BS горизонт Верхний Кельвассер, интервал черных сланцев, UKH CIE - горизонт Верхний Кельвассер, интервал изотопных отклонений углерода

Conodonts provide a biostratigraphic framework for the studied succession. Conodonts were obtained from carbonate rocks by dissolving in $10 \%$ buffered acetic acid. Clay rocks were soaked in water and washed through a $0.05-0.1 \mathrm{~mm}$ sieve. We processed more than $40 \mathrm{sam}-$ ples of 1 to $2 \mathrm{~kg}$ in weight. Conodont biofacies were established based on the identified distribution intervals of the prevailing taxa. The conodont elements obtained from the Kozhym River section are well preserved and have a conodont colour alteration index (CAI) between 4 and 5 (dark brown to black). The conodonts were photographed using a Tescan Vega 3 LMH scanning electron microscope.

Powders for isotopic-geochemical analysis, drilled mainly from the micrite part of carbonate rocks, as well as thin sections for analysis of lithotypes were made from all samples. The isotope data of carbonate rocks was studied in order to reconstruct the carbon and oxygen variation curves, to identify the features of changes in carbon and oxygen isotope composition, and to compare the data obtained with the results of studies of carbonate rocks from other sections of the world. Isotopic-geochemical analyzes were performed at the Geoscience Center of the Institute of Geology Komi SC UrB RAS (Syktyvkar, Russia) on an analytical complex that includes the Gas Bench II sample preparation and input system connected to the DELTA V Advantage mass spectrometer by Thermo Fisher Scientific (Bremen, Germany). The $\delta^{13} \mathrm{C}$ values are reported relative to the PDB standard and $\delta^{18} \mathrm{O}$ - to the SMOW standard. The collection of conodonts, thin sections and materials are housed in the A. A. Chernov Geological Museum of the Institute of Geology, coll. no. 492/3b, 492/5, 492/10 (Syktyvkar, Russia).

\section{Results}

The Kozhym River section (30 m thick), previously studied in detail [18], contains a large number of conodonts, ostracodes, radiolarians, sponge spicules, trilobites, brachiopods, bivalves, tentaculites, orthoceratids, ammonoids, etc. The rocks of the section contain all-skeletal remnants of free-floating marine organisms and thin- 
shelled benthos, which are characteristic of a calm deep sedimentation environment. The lower part of the section (beds $1-12$ ) is characterized by the presence of beds of organogenic and bioclastic mud-wacke-pack-grainstone (ammonoids, tentaculites and ostracodes) with a slight fine-grained admixture of shell detritus on a background of calcareous-clayey-siliceous sedimentation. The upper part of the section (beds 13-21) is mainly characterized by micritic carbonate-clay sedimentation (mud-wackestone) with an insignificant content of benthic organisms of fine preservation and with articulated shells. The rocks of the section contain organic matter, which gives them a dark gray, almost black color. The stratigraphic range of the section covers the interval from the lowermost Frasnian to the Lower Famennian (Lower falsiovalis - Lower triangularis conodont subzones). We focused on the F-F boundary interval and the corresponding lithological beds 20 and 21 (Upper rhenana - Lower triangularis conodont subzones).

\section{Lithology}

The lithological succession across the F-F boundary of the Kozhym River section is presented by beds 20 and 21 of the Vorota Formation. Below is a brief description of the section (Fig. 2):

Bed 20. Alternation of gray to dark-gray limestones and gray to black shales. Limestones are mostly microgranular (mud-wackestone) and unevenly recrystallized with a lumpy-patterned structure (Fig. 3). There are pelitic limestones (mudstone) with scattered bioclasts. In the upper part there is limestone with sulfide blotches of a lenticular form and black shales with black microgranular limestones lenses, and insignificant content of ostracodes, tentaculites, radiolarians and conodonts. The calcareous shales sometimes contain rare grains of quartz silt dimension, scattered organic matter, whole shells of benthic and plankton ostracodes and radiolarians. $2.9 \mathrm{~m}$ thick.

Bed 21. Dark-gray micro-fine-granular siliceous-claycarbonaceous limestones (wacke-packstone, Fig. 3), containing whole skeletal remains of radiolarians, thin-walled ostracodes, brachiopods and conodonts. Some microgranular limestones demonstrate a clotted patterned structure. Fine-grained limestone (wackestone) shows the microlayered redistribution of stratified clay-carbonaceous material. Gray microlayered siliceous limestones lie at the top of the Bed 21. $2.7 \mathrm{~m}$ thick.

Pelitomorphic microgranular deposit indicates that sedimentation occurred in relatively deep-water environments, below the wave basis, which contributed to the accumulation of sludge material. The layering due to the subparallel distribution of fossils/interlayers saturated with clay or organic matter was probably caused by frequent changes in the hydrodynamic regime. Benthic organisms with fine preservation and articulated shells, such as ostracodes and brachiopods, indicate a quiet hydrodynamic regime. A large number of buried planktonic organisms cause increased organic matter content in the deposits. All these signs indicate a deep water deposition below the wave base.

The formation of clay-siliceous-carbonaceous sediments against a background of pure carbonate silts is interpreted as an increase in relative sea level. The formation of carbonate sediments with an admixture of middlecoarse-grained detrital material is interpreted as a decrease in relative sea level. The distribution of lithological types in the section allows reconstruction of sea level fluctuations. Three transgression-regression cycles can be recognized at the top of Bed 20 (Fig. 2).

\section{Conodont biostratigraphy}

Conodont distribution in the Vorota Formation of the Kozhym River section was analyzed. The standard conodont zonation [22] for Upper Frasnian and the conodont zonation [19] for Lower Famennian were used as a biostratigraphic framework. Abbreviations used: And. Ancyrodella, Anc. - Ancyrognathus, Icr. - Icriodus, Pal. Palmatolepis, Pol. - Polygnathus.

Upper Devonian, Frasnian. The Upper rhenana Subzone is recognized by the first occurrence of Pal. subrecta Miller et Youngquist and Pal. gigas extensa Ziegler et Sandberg in sample 107/27** (Fig. 4). It is represented by an interval more than $7 \mathrm{~m}$ thick. This subzone is almost equivalent to the 13a Montagne Noire Zone [7] and to the bogartensis conodont Zone [2]. The base of the Upper rhenana Subzone is defined by the first appearance of Pal. rhenana rhenana Bischoff in the standard conodont zonation. In the studied section, Pal. rhenana rhenana Bischoff firstly appears together with Pal. juntionensis Han much higher, in sample 106/2a. Predominantly, conodonts of Palmatolepis are abundant on the level of the Upper rhenana Subzone. The conodonts are dominated by Pal. subrecta Miller et Youngquist, Pal. rhenana nasuta Müller, Pal.jamieae Ziegler et Sandberg, Pal. foliacea Youngquist, Pal. kireevae Ovnatanova, Pol. lodinensis Polsler in the lower part of the Upper rhenana Subzone (Outcrop 107, after [18]). The conodonts are few, and dominated by Pal. juntionensis Han, Pal. rhenana rhenana Bischoff, Pal. eureka Ziegler et Sandberg, Pal. ederi Ziegler et Sandberg, Pal. lyaiolensis Khrustcheva et Kuzmin, Pal. bogartensis (Stauffer), Pol. lodinensis Polsler in the upper part of the Upper rhenana Subzone (Outcrop 106, after [18]). Pal. subrecta Miller et Youngquist is an additional marker of the base of the Upper rhenana Subzone [22]. This species is found at the base of the Upper rhenana Subzone in sections of Southern China [4] and the Subpolar Urals in Russia [18, 21]. Fig. 2 partially shows the interval of the Upper rhenana Subzone.

The linguiformis Zone is marked by the first occurrence of Pal. linguiformis Müller in sample 106/14 (Figs. 2, $5)$. It is represented by an interval about $0.8 \mathrm{~m}$ thick if we count before the first appearance of Pal. subperlobata Branson et Mehl in sample 106/23. The linguiformis Zone has been subdivided into a lower part defined by the total distribution range of Pal. linguiformis Müller and an upper part defined by the Ancyrognathus ubiquitous Zone [2]. These zones are equivalent to the Montagne Noire zones $13 \mathrm{~b}$ and $13 \mathrm{c}$ [7]. In the studied section, conodonts are dominated by Pal. linguiformis Müller, Pal. zhuravlevi Soboleva, Pal. juntionensis Han, Pal. ederi Ziegler et Sandberg, Anc. seddoni Klapper and Pol. lodinensis Polsler (Fig. 5). This level is closely below the base of the Upper Kellwasser Event (global biological crisis), therefore it is characterized by a low conodont diversity. Most Frasnian conodonts became extinct in the upper part of this zone. The zone is recognizable worldwide [1, 4, 13, 16, 18, 21-22, etc.].

Upper Devonian, Famennian. The subperlobata Zone is recognized by the first occurrence of Pal. subperlobata Branson et Mehl in sample 106/23 (Figs. 2, 6). It is represented by an interval about $0.7 \mathrm{~m}$ thick. The subperlobata Zone [19] is equivalent to the lower part of the Lower tri- 


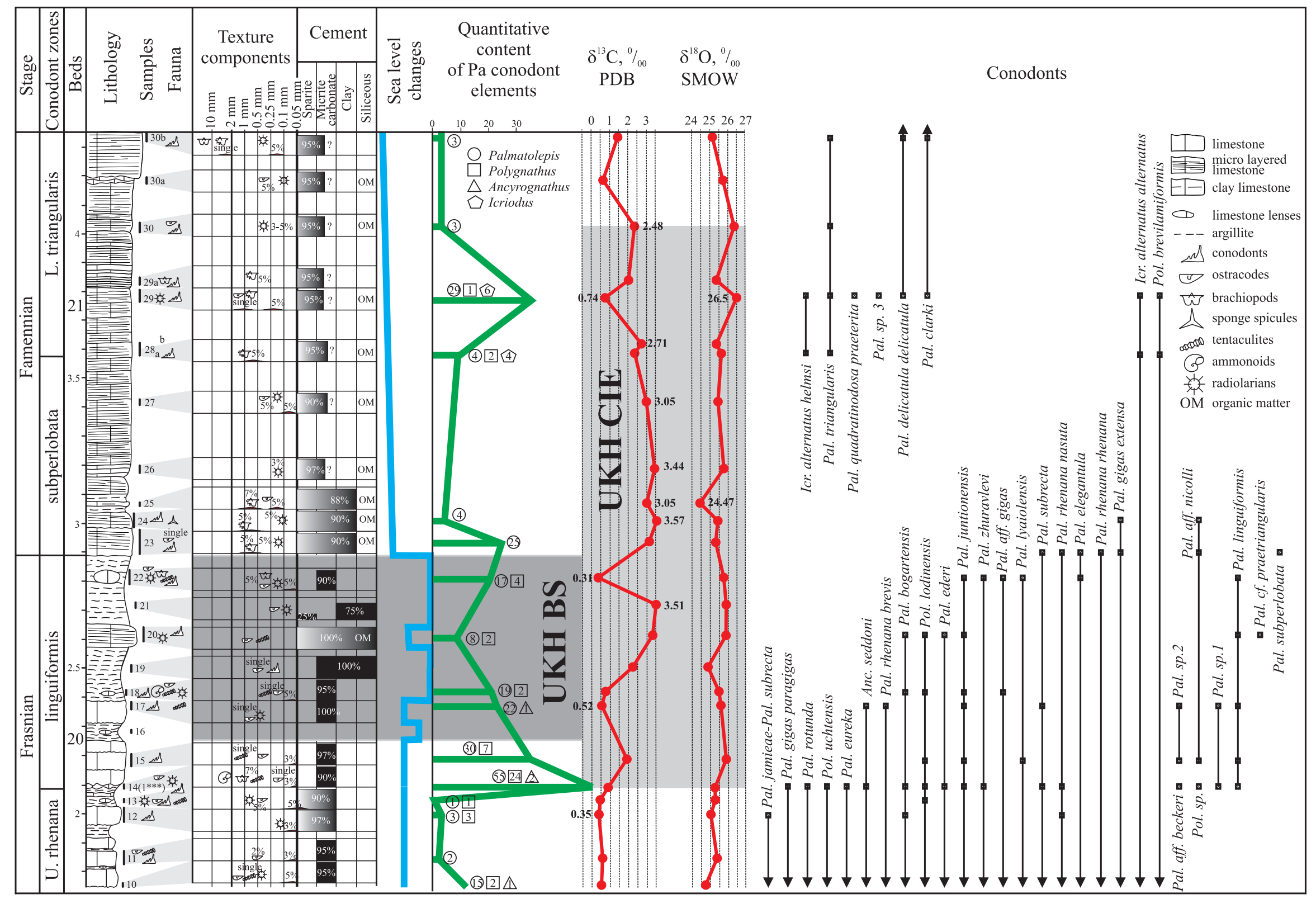

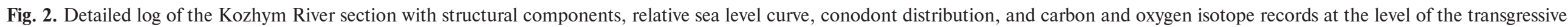
Upper Kellwasser Event

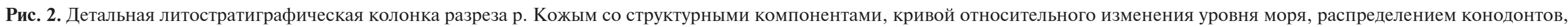
изотопами углерода и кислорода на уровне трансгрессивного события Верхний Кельвассер 

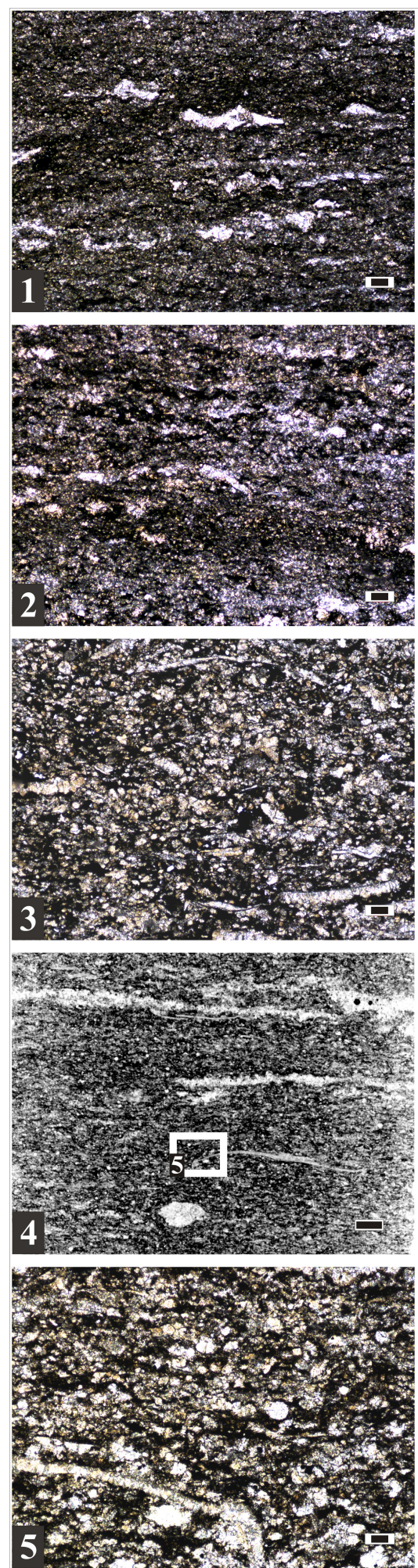

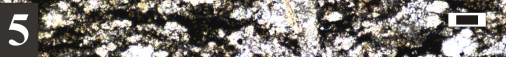
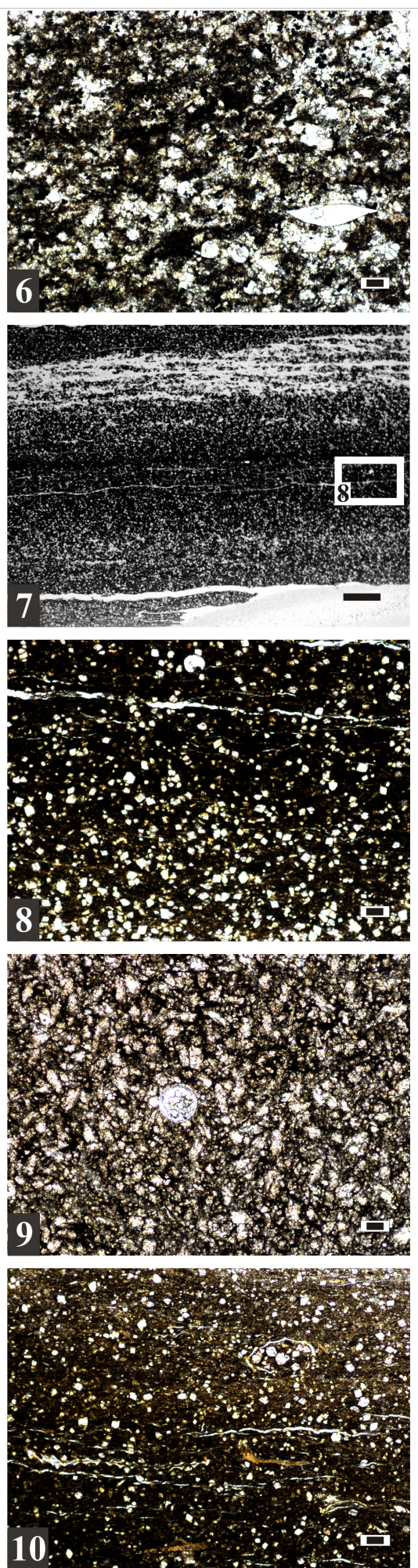
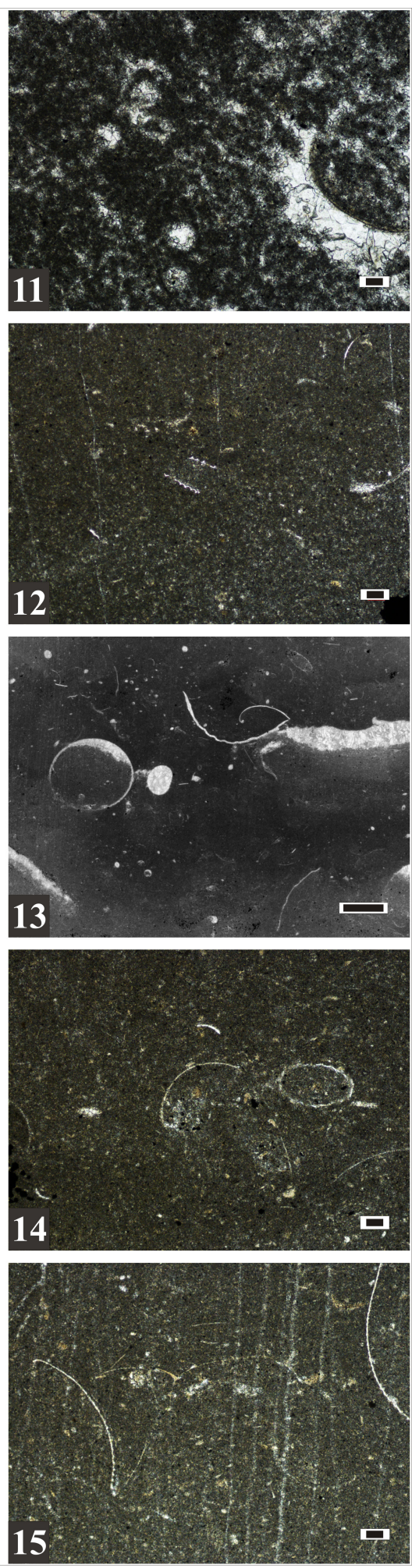

Fig. 3. Microphotographs of selected facies types:

1-6 - Fine-grained bioclastic microlaminated wackestones: 1 - sample 106/28b; 2 - sample 106/27; 3 - sample 106/25; 4, 5 - sample 106/24; 6 sample 106/23. The bioclasts are dominated by thin shells of the brachiopod and ostracodes. There are unbroken ostracodes and radiolarians. The micritic matrix has recrystallized to fine-grained calciticmicrospar. 7, 8, 10 - Black shales: 7, 8 - sample 106/21, with radiolarians?; 10 - sample 106/19, with Entomozoida ostracodes, radiolarians? and conodonts; 9 - Mudstone with a recrystallized fine-grained calciticmicrospar, sample 106/20; 11 - Recrystallized mud-wackstone with ostracodes and radiolarians, sample 106/17; 12-15 - Mudstone with ostracodes carapaces and shells and tentaculites: 12 - sample

106/15; 13-14 - sample 106/14; 15 - sample 106/11. Scale bar for all images is $100 \mu \mathrm{m}$, except for figs. 4 and 7 is $1000 \mu \mathrm{m}$ and for fig. 13 is $2000 \mu \mathrm{m}$

Рис. 3. Отдельные фациальные типы пород:

1-6 - мелкозернистые биокластовые микрослоистые вакстоны: 1 - образец 106/28b; 2 - образец 106/27; 3 - образец 106/25; 4, 5 - образец 106/24; 6 - образец 106/23. В биокластах преобладают тонкие раковины брахиопод и остракод. Есть неразрушенные остракоды и радиолярии. Микритовый матрикс перекристаллизован в мелкозернистый кальцит. 7, 8, 10 - черные аргиллиты: 7, 8 - образец 106/21 с радиоляриями (?); 10 - образец 106/19 с энтомозоидными остракодами, радиоляриями (?) и конодонтами; 9 - мадстоун с перекристаллизованным мелкозернистым кальцитом, образец 106/20; 11 - перекристаллизованный мад-вакстоун с остракодами и радиоляриями, образец 106/17; 12-15 мадстоун с целыми и разрозненными створками остракод и тентакулитами: 12 - образец 106/15; 13, 14 - образец 106/14; 15 - образец 106/11. Масштабная линейка для всех изображений - 100 мкм, для фиг. 4 и $7-1000$ мкм, для фиг. $13-2000$ мкм 


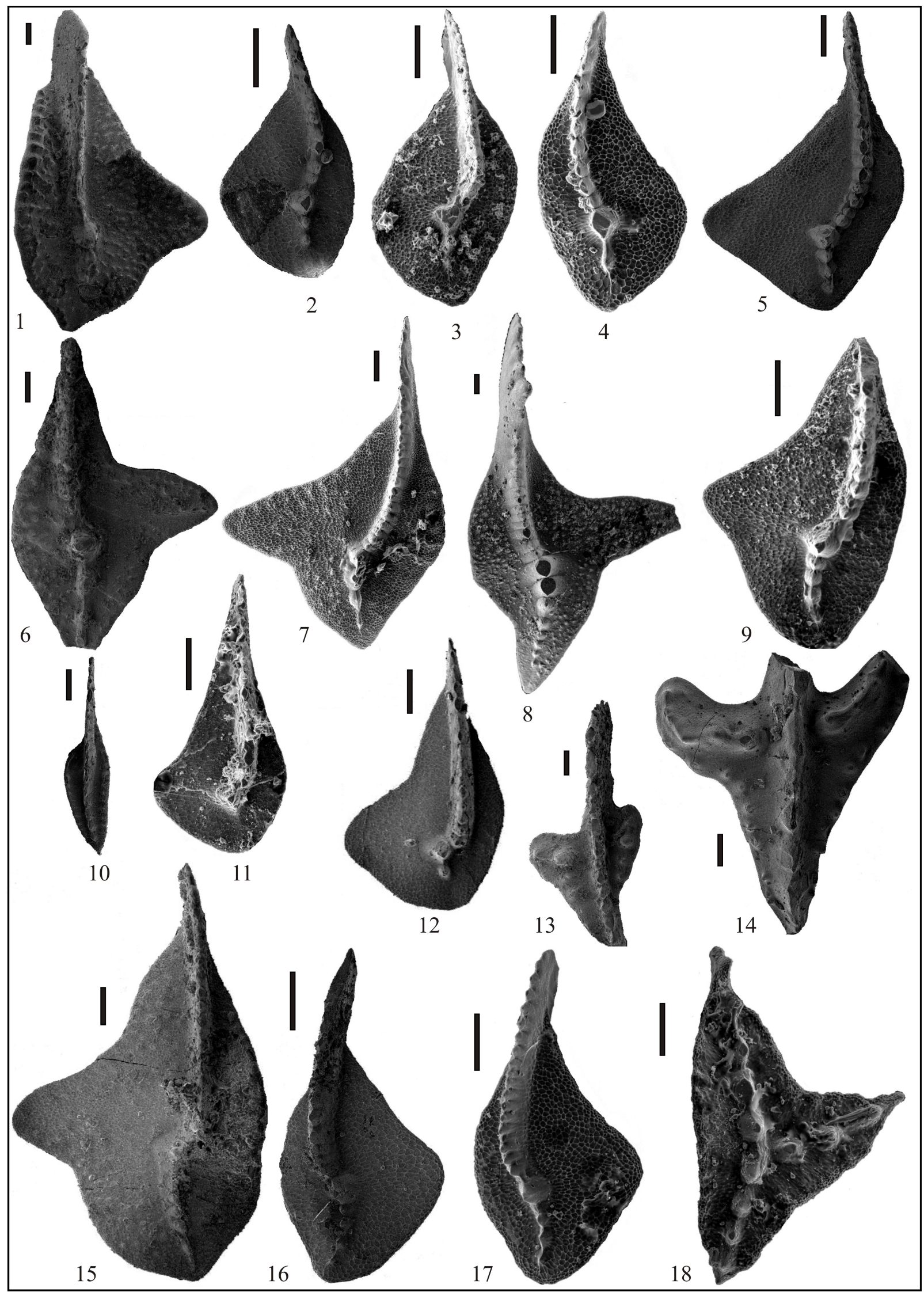

Fig. 4. The Upper Frasnian conodonts from the Kozhym River section. All are Pa elements and upper view:

1 - Palmatolepis subrecta Miller et Youngquist, 492/5-24, sample 107/27**; 2, 3 - Palmatolepis eureka Ziegler et Sandberg, (2) 492/3b-48, sample 106/4***; (3) 492/10-6, sample 106/2a; 4 - Palmatolepis ederi Ziegler et Sandberg, 492/10-7, sample 106/4a; 5 - Palmatolepis sp., 492/3b-51, sample 106/4***; 6 - Palmatolepis aff. gigas paragigas Ziegler et Sandberg, 492/3b-49, sample 106/4***; 7 - Palmatolepis aff. mucronata Klapper, Kuzmin et Ovnatanova, 492/10-8, sample 106/4a; 8 - Palmatolepis rhenana rhenana Bischoff, 492/10-3, sample 106/2a; 9, 15 - Palmatolepis rotunda Ziegler et Sandberg, (9) 492/10-5, sample 106/2a; (15) 492/3b-34, sample 106/2***; 10 - Polygnathus lodinensis Polsler, 492/3b-37, sample 106/2***; 11, 12 Palmatolepis juntionensis Han, (11) 492/10-4, sample 106/2a; (12) 492/3b-33, sample 106/2***; 13 - Ancyrodella nodosa Ulrich et Bassler, 492/3b-42, sample 106/3***; 14 - Ancyrodella ioides Ziegler, 492/3b-29, sample 106/2***; 16, 17 - Palmatolepis timanensis Klapper, Kuzmin et Ovnatanova, (16) 492/3b-38, sample 106/2***; (17) 492/10-12, sample 106/9; 18 - Ancyrognathus amana Miller et Miller, 492/10-11, sample 106/9. Scale bar is $100 \mu \mathrm{m}$ 


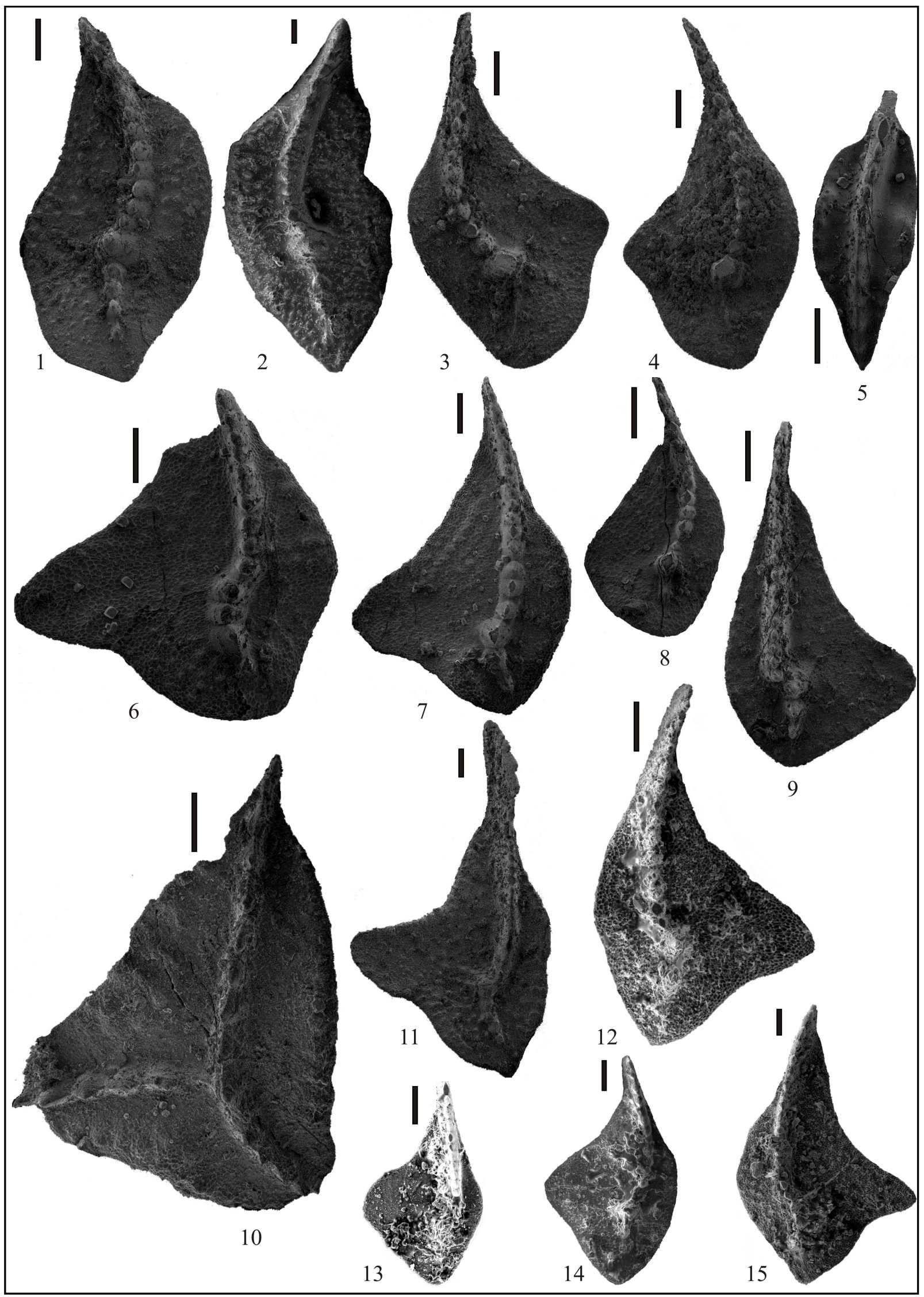

Fig. 5. The Upper Frasnian conodonts from the Kozhym River section. All are Pa elements and upper view:

1, 2 - Palmatolepis linguiformis Müller, (1) 492/3b-5, sample 106/14; (2) 492/10-19, sample 106/17; 3, 4 - Palmatolepis zhuravlevi Soboleva, (3) 492/3b-7 (holotype), sample 106/14; (4) 492/3b-9, sample 106/14; 5 - Polygnathus sp., 492/3b-24, sample 106/14; 6, 7 - Palmatolepis aff. beckeri Klapper, (6) 492/3b17, sample 106/14; (7) 492/3b-23, sample 106/14; 8 - Palmatolepis eureka Ziegler et Sandberg, 492/3b-15, sample 106/14; 9 - Palmatolepis juntionensis Han, 492/3b-2, sample 106/14; 10 - Ancyrognathus seddoni Klapper, 492/3b-16, sample 106/14; 11 - Palmatolepis gigas paragigas Ziegler et Sandberg, 492/3b27, sample 106/14; 12, 15 - Palmatolepis sp. 1, (12) 492/10-14, sample 106/15; (15) 492/10-17, sample 106/17; 13, 14 - Palmatolepis sp. 2, (13) 492/10-16, sample $106 / 15$; (14) $492 / 10-20$, sample $106 / 17$. Scale bar is $100 \mu \mathrm{m}$ 


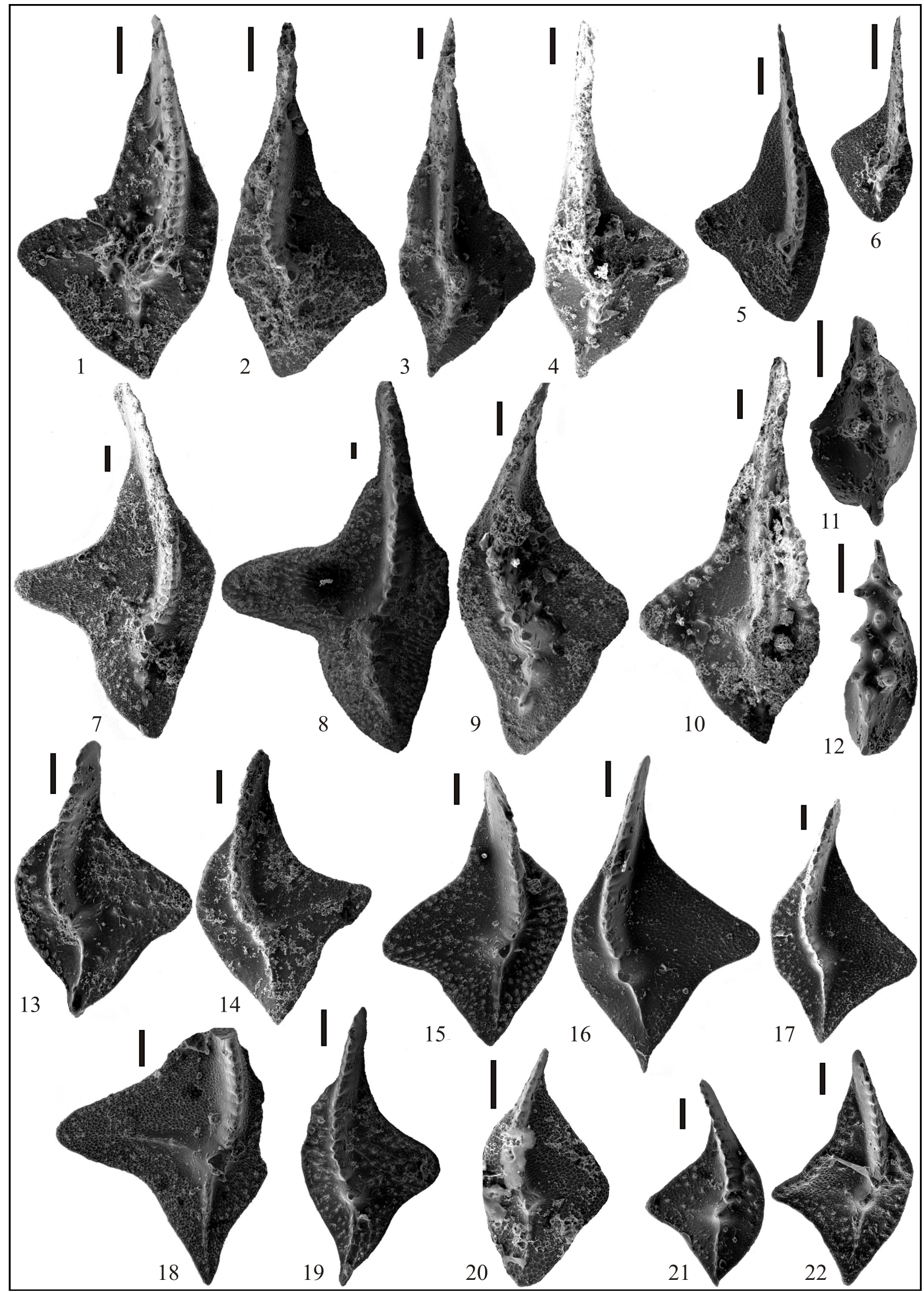

Fig. 6. The Lower Famennian conodonts from the Kozhym River section. All are Pa elements and upper view:

1, 2, 3, 10 - Palmatolepis gigas extensa Ziegler et Sandberg, (1) 492/10-23, sample 106/23; (2) 492/10-25, sample 106/23; (3) 492/10-26, sample 106/23; (10) 492/10-34, sample 106/24; 4, 5 - Palmatolepis aff. nicolli Klapper, (4) 492/10-27, sample 106/23; (5) 492/10-28, sample 106/23; 6 - Palmatolepis elegantula Wang et Ziegler, 492/10-29, sample 106/23; 7, 8 - Palmatolepis rhenana nasuta Müller, (7) 492/10-30, sample 106/23; (8) 492/10-31, sample 106/23; 9 - Palmatolepis subperlobata Branson et Mehl, 492/10-33, sample 106/23; 11 - Icriodus alternatus helmsi Sandberg et Dreesen, 492/10-35, sample 106/28a; 12 - Icriodus alternatus alternatus Branson et Mehl, 492/10-38, sample 106/28a; 13, 14, 16, 17, 19 - Palmatolepis triangularis Sannemann, (13) 492/10-36, sample 106/28a; (14) 492/10-37, sample 106/28a; (16) 492/10-47, sample 106/29; (17) 492/10-41, sample 106/29; (19) 492/10-48 (aff.), sample 106/30; 15 - Palmatolepis quadratinodosalobata praeterita Schulke, 492/10-42, sample 106/29; 18 - Palmatolepis sp. 3, 492/10-43, sample 106/29; 20 - Palmatolepis delicatula delicatula Branson et Mehl, 492/10-49, sample 106/30b; 21, 22 - Palmatolepis clarki Ziegler, (21) 492/10-46, sample 106/29; (22) $492 / 10-52$, sample $106 / 33$. Scale bar is $100 \mu \mathrm{m}$ 
Рис. 4. Верхнефранские конодонты разреза р. Кожым. Все экземпляры - Ра-элементы (вид сверху): 1 - Palmatolepis subrecta Miller et Youngquist, 492/5-24, образец 107/27**; 2, 3 - Palmatolepis eureka Ziegler et Sandberg, (2) 492/3b-48, образец 106/4***; (3) 492/10-6, образец 106/2a; 4 - Palmatolepis ederi Ziegler et Sandberg, 492/10 - 7, образец 106/4a; 5 - Palmatolepis sp., 492/3b-51, oбpaзец 106/4***; 6 - Palmatolepis aff. gigas paragigas Ziegler et Sandberg, 492/3b-49, образец 106/4***; 7 - Palmatolepis aff. mucronata Klapper, Kuzmin et Ovnatanova, 492/10-8, образец 106/4a; 8 - Palmatolepis rhenana rhenana Bischoff, 492/10-3, образец 106/2a; 9, 15 - Palmatolepis rotunda Ziegler et Sandberg, (9) 492/10-5, образец 106/2a; (15) 492/3b-34, образец 106/2***; 10 - Polygnathus lodinensis Polsler, 492/3b-37, образец 106/2***; 11, 12 - Palmatolepis juntionensis Han, (11) 492/10-4, образец 106/2a; (12) 492/3b-33, образец 106/2***; 13 - Ancyrodella nodosa Ulrich et Bassler, 492/3b-42, образец 106/3***; 14 - Ancyrodella ioides Ziegler, 492/3b-29, образец 106/2***; 16, 17 - Palmatolepis timanensis Klapper, Kuzmin et Ovnatanova, (16) 492/3b-38, образец 106/2***; (17) 492/10-12, образец 106/9; 18 - Ancyrognathus amana Miller et Miller, 492/10-11, образец 106/9. Масштабная линейка 100 мкм

Рис. 5. Верхнефранские конодонты разреза р. Кожым. Все экземпляры - Ра-элементы (вид сверху): 1, 2 - Palmatolepis linguiformis Müller, (1) 492/3b-5, образец 106/14; (2) 492/10-19, образец 106/17; 3, 4 - Palmatolepis zhuravlevi Soboleva, (3) 492/3b-7 (голотип), образец 106/14; (4) 492/3b-9, образец 106/14; 5 - Polygnathus sp., 492/3b-24, образец 106/14; 6, 7 - Palmatolepis aff. beckeri Klapper, (6) 492/3b-17, образец 106/14; (7) 492/3b-23, образец 106/14; 8 - Palmatolepis eureka Ziegler et Sandberg, 492/3b-15, образец 106/14; 9 Palmatolepis juntionensis Han, 492/3b-2, образец 106/14; 10 - Ancyrognathus seddoni Klapper, 492/3b-16, образец 106/14; 11 - Palmatolepis gigas paragigas Ziegler et Sandberg, 492/3b-27, образец 106/14; 12, 15 - Palmatolepis sp. 1, (12) 492/10-14, образец 106/15; (15) 492/10-17, образец 106/17; 13, 14 - Palmatolepis sp. 2, (13) 492/10-16, образец 106/15; (14) 492/10-20, образец 106/17. Масштабная линейка 100 мкм

Рис. 6. Нижнефаменские конодонты разреза р. Кожым. Все экземпляры - Ра-элементы (вид сверху):

1, 2, 3, 10 - Palmatolepis gigas extensa Ziegler et Sandberg, (1) 492/10-23, образец 106/23; (2) 492/10-25, образец 106/23; (3) 492/10-26, образец 106/23; (10) 492/10-34, образец 106/24; 4, 5 - Palmatolepis aff. nicolli Klapper, (4) 492/10-27, образец 106/23; (5) 492/10-28, образец 106/23; 6 Palmatolepis elegantula Wang et Ziegler, 492/10-29, образец 106/23; 7, 8 - Palmatolepis rhenana nasuta Müller, (7) 492/10-30, образец 106/23; (8) 492/10-31, образец 106/23; 9 - Palmatolepis subperlobata Branson et Mehl, 492/10-33, образец 106/23; 11 - Icriodus alternatus helmsi Sandberg et Dreesen, 492/10-35, образец 106/28a; 12 - Icriodus alternatus alternatus Branson et Mehl, 492/10-38, образец 106/28a; 13, 14, 16, 17, 19 - Palmatolepis triangularis Sannemann, (13) 492/10-36, образец 106/28a; (14) 492/10-37, образец 106/28a; (16) 492/10-47, образец 106/29; (17) 492/10-41, образец 106/29; (19) 492/10-48 (aff.), образец 106/30; 15 - Palmatolepis quadratinodosalobata praeterita Schulke, 492/10-42, образец 106/29; 18 - Palmatolepis sp. 3, 492/10-43, образец 106/29; 20 - Palmatolepis delicatula delicatula Branson et Meh1, 492/10-49, образец 106/30b; 21, 22 - Palmatolepis clarki Ziegler, (21) 492/10-46, образец 106/29; (22) 492/10-52, образец 106/33. Масштабная линейка 100 мкм

angularis Subzone [22]. However, this correlation with zonation [22] is incorrect, since the appearance of Pal. triangularis Sannemann is noted somewhat higher than the first appearance of Pal. subperlobata Branson et Mehl. This confusion results from the fact that the name of the species Pal. triangularis Sannemann is applied by some authors to the species Pal. praetriangularis Ziegler and Sandberg, 1988 which is a junior synonym of Pal. ultima Ziegler [8]. In the studied section, Pal. triangularis Sannemann is distributed somewhat higher than the appearance of Pal. subperlobata Branson et Mehl. We think that, the lowest appearance of Pal. subperlobata Branson et Mehl may be used to characterize the F-F boundary immediately above the Upper Kellwasser Event. Conodonts are dominated by Pal. gigas extensa Ziegler et Sandberg, Pal. rhenana nasuta Müller, Pal. elegantula Wang et Ziegler. Pal. aff. nicolli Klapper within this zone (Fig. 6). This level is characterized by a low diversity conodont at the base of this zone and is practically barren of conodonts higher. The subperlobata Zone is recognizable in some areas $[4,8-9,19]$.

The triangularis Zone is recognized by the first occurrence of Pal. triangularis Sannemann in sample 106/28a (Figs. 2, 6). In the studied section, conodonts are dominated by Icr. alternatus alternatus Branson et Mehl and Icr. alternatus helmsi Sandberg et Dreesen, Pol. brevilamiformis Ovnatanova, slightly higher Pal. clarki Ziegler, Pal. delicatula delicatula Branson et Mehl, Pal. quadratinodosalobata praeterita Schulke et al (Fig. 6).

Conodont biofacies of the Kozhym River section were discussed in details earlier [15, 18]. The conodonts represent a deep-sea marine fauna, which exhibits a Palmatolepid biofacies, where Palmatolepis species dominate (Fig. 2) [6]. However, the depth of the sea basin was not constant, which is reflected in changes in the quantitative content of the deep-water conodonts of Palmatolepis $[15,18]$. The maximum deepening of the basin was reached at the beginning of the linguiformis Phase, which is ex- pressed by a sharp increase and stable development of the Palmatolepid biofacies (Fig. 2). Deepening affected the numerical and species diversity of conodonts, to the complete disappearance of many taxa by the end of Frasnian time [15]. During the transition to the subperlobata Phase, there is a significant decrease in conodont diversity, possibly associated with a sea level drop. This method, based on the changing quantitative content of deep-water conodonts, has revealed the occurrence of oscillations in sealevel in the section studied and Kosyu River section in spite of initial doubts [15, 17-18].

\section{Carbon and oxygen isotopes}

The carbon and oxygen isotope values across the F-F boundary in the studied section vary in the range: from 0.31 to $3.57 \%$ for $\delta^{13} \mathrm{C}$ and from 24.34 to $26.50 \%$ for $\delta^{18} \mathrm{O}$ (Fig. 2). In the interval characterized by upper part of Upper rhenana Subzone, a stable $\delta^{13} \mathrm{C}$ value from 0.35 to $0.64 \%$ is observed with weak deviations. In the linguiformis Zone, abrupt changes in the $\delta^{13} \mathrm{C}$ values from 0.52 to $3.51 \%$ are observed. Increased values in black shales, fixing record maximum transgressions are recorded. The highest positive $\delta^{13} \mathrm{C}$ value is $3.51 \%$ (sample 106/21) and drops in the third bed of black shales in the upper part of linguiformis Zone. The positive $\delta^{13} \mathrm{C}$ value of $3.19 \%$ (sample 106/23) correlates with the F-F boundary. In the interval characterized by the subperlobata Zone, $\delta^{13} \mathrm{C}$ values are raised from 3.05 to $3.57 \%$. Continuing high $\delta^{13} \mathrm{C}$ values are observed throughout the subperlobata Zone and Lower triangularis Subzone with a tendency to a gradual decrease to $0.69 \%$. Similar positive shift in $\delta^{13} \mathrm{C}$ values during the Upper Kellwasser Event was observed in various sections of Central, Southern, and Eastern Europe, as well as North America and North Africa [3, 5, 11, 13, 21, etc.].

The oxygen isotope composition in the section slightly varies from 24.34 to $26.50 \%$. 


\section{Discussion}

The Global Stratotype Section and Point (GSSP) for the $\mathrm{F}-\mathrm{F}$ boundary is designated at Coumiac in the Montagne Noire of southern France [10]. High-precision identification of this boundary is best based on conodonts. The $\mathrm{F}-\mathrm{F}$ boundary interval corresponds to one of the largest extinction event in the Middle Paleozoic. The Upper Kellwasser Event corresponds to the linguiformis conodont Zone [20] and is considered a first-order global event characterized by the mass extinction of major fossil groups (classes and orders) and of entire ecosystems [2].

In many stratigraphic sections, the Upper Kellwasser Event is observed as an anoxic black shales horizon associated with shifts in many geochemical indicators, among them stable carbon isotopes [3-5, 11-14, 18, 20-21]. The UKH BS (Black Shales Interval) Event and the UKH CIE (Carbon Isotope Excursion Interval) Event are recognized (Fig. 1, C).

In the Kozhym River section, significant biotic changes are recorded from the base of the linguiformis Zone, where there is a sharp but short-term increase in the taxonomic diversity of conodonts (Fig. 2). Above this level, an increase in the carbon isotopic composition from 0.35 to $1.96 \%$ is noted. The next three levels of accumulation of anoxic black shales with a rare pelagic fauna (radiolarians and Entomozoid-type ostracodes) record transgression, which lasted until the end of the linguiformis Phase. A lack of intra-basinal clastic material is distinguished at this level. Here, a gradual decrease in taxonomic diversity and the disappearance of Frasnian conodonts are recorded, while $\delta^{13} \mathrm{C}$ values increase up to $3.51 \%$. In some samples, lower $\delta^{13} \mathrm{C}$ values are observed, which vary from 0.31 to $0.75 \%$ (samples $106 / 17,106 / 18,106 / 22$ ). This is probably due to diagenetic transformations during the formation of carbonate lenses, which led to a relief of the carbon isotopic composition.

At the beginning of the subperlobata Phase, a significant increase in the size of organogenic-bioclastic material is observed, which is associated with a relative decrease in sea level. Microlayered structures and fragments of brachiopods in dark gray limestones (wacke-packstone) appear. A sharp decrease in the species diversity of conodonts occurs [15]. The $\delta^{13} \mathrm{C}$ values remain high, but gradually decrease from 3.57 to $3.35 \%$.

The subsequent triangularis Phase is characterized by a slight increase in the species diversity of the Palmatolepid biofacies (Fig. 2). The composition of the deposits does not change, and the values of $\delta^{13} \mathrm{C}$ gradually decrease to $0.69 \%$.

Thus, the linguiformis Zone of the Kozhym River section clearly fixes the transgressive level, probably corresponding to the UKH BS Event, as well as the UKH CIE Event, covering the linguiformis Zone, the subperlobata Zone and the Lower triangularis Subzone (Fig. 2).

As noted earlier, similar changes in the carbon isotope values during the Upper Kellwasser Event are observed worldwide. Positive $\delta^{13} \mathrm{C}$ shifts are generally explained as a result of enhanced organic carbon burial or increased marine productivity. Positive shifts of the carbon isotope value near the F-F boundary were distinguished in the TimanNorth Urals Region sections both in extremely shallow deposits of Southern Timan with a deviation of $4.5 \%$ [11], and in the deep-sea shelf deposits of the Subpolar Urals with a reference of $3.5 \%$ [21]. According to [21] un- steady eutrophic and oxygen-depleted ecosystems during the Frasnian-Famennian Event were intensified by various episodes of tectono-volcanic events in the closing Ural Ocean. These events were interpreted based on a detailed study of the Syvyu River section [21] is located in close proximity to the Kozhym River section.

\section{Conclusions}

The Frasnian-Famennian boundary interval of the Kozhym River section consists mainly of limestones (mudwackestone) and black shales (Bed 20) and siliceous-claycarbonaceous limestones (wacke-packstone, Bed 21) accumulated in relatively deep-water environments, below the wave basis. The layering due to the subparallel distribution of fossils/interlayers saturated with clay or organic matter was probably caused by frequent changes in the hydrodynamic regime. Three transgression-regression cycles were recognized at the top of Bed 20.

The Kozhym River section contain a large number of fossils including conodonts. The conodonts of the Bed 20 are represented by the assemblage of the Frasnian Upper rhenana Subzone (upper part) and linguiformis Zone. The conodonts of the Bed 21 are represented by the assemblage of the Famennian subperlobata Zone and Lower triangularis Subzone (lower part). The F-F boundary was identified by the first occurrence of Palmatolepis subperlobata in sample 106/23 (Bed 21). Conodonts are abundant in the Upper rhenana Subzone, but are almost absent in the subperlobata Zone.

Black shale horizons associated with the global Upper Kellwasser Event were identified in the linguiformis Zone in the Kozhym River section. Positive shifts in the carbon isotope ratio during the linguiformis Zone to the Lower triangularis Subzone (lower part) are observed, similar to those reported from elsewhere around the world (positive $\delta^{13} C_{\text {carb }}$ shifts $\sim$ from 3 to $4 \%$ ). In the linguiformis Zone (upper part) at the level of third of black shale horizon a gradual decrease in taxonomic diversity and the disappearance of Frasnian conodonts are recorded, while $\delta^{13} \mathrm{C}$ values increase up to $3.51 \%$. The maximum $\delta^{13} \mathrm{C}$ value of $3.57 \%$ is observed just above the Frasnian-Famennian boundary.

The data obtained allow the black shale horizons associated with the Upper Kellwasser Event and carbon isotope fluctuations to be precisely dated and correlated.

Acknowledgements. We thank A. V. Zhuravlev and $S$. V. Nikolaeva for assistance in writing the English text and constructive comments that substantially improved this article. Also we thank E. M. Tropnikov and A. S. Shuyskiy for SEM assistance, and I. V. Smoleva for isotope data.

\section{References}

1. Aung A. K., Hassan M. H. A., Fatt N. T. Discovery of Late Devonian (Frasnian) conodonts from the "Sanai limestone", Guar Jentik, Perlis, Malaysia. Bulletin of the Geological Society of Malaysia, 2013, V. 59, pp. 93-99.

2. Becker R. T., Konigshof P., Brett C. E. Devonian climate, sea level and evolutionary events-an introduction. Becker R. T., Konigshof P., Brett C. E. (Eds.). Devonian climate, sealevel and evolutionary events. Geological Society London, Special Publication 423, 2016, pp. 1-10. 
3. Buggisch W., Joachimski M. M. Carbon isotope stratigraphy of the Devonian of Central and Southern Europe. Palaeogeogr., Palaeoclimat., Palaeoecol., 2006, V. 240, pp. 68-88.

4. Huang C., Song J., Shend J., Gongb Y. The influence of the Late Devonian Kellwasser events on deep-water ecosystems: Evidence from palaeontological and geochemical records from South China. Palaeogeogr., Palaeoclimat., Palaeoecol., 2018, V. 504, pp. 60-74.

5. Joachimski M. M., Pancost R. D., Freeman K. H., Ostertag-Henning C., Buggisch W. Carbon isotope geochemistry of the Frasnian-Famennian transition. Palaeogeogr., Palaeoclimat., Palaeoecol., 2002, V. 181, pp. 91-109.

6. Kirilishina E. M., Kononova L. I. Konodontovyye biofatsii vo franskom basseyne yugo-zapada Moskovskoy sinekli$z y$. (Conodont biofacies in frasnian basin of south-western part of Moscow syneclise). Vestnik Moskovskogo universiteta. Ser. 4. Geologiya, 2004, No. 2, pp. 32-40.

7. Klapper G. The Montagne Noire Frasnian (Upper Devonian) conodont succession. McMillan N. J., Embry A. F., Glass D. J. (Eds.). Devonian of the World: Proceedings of the 2nd International Symposium on the Devonian System. Can. Soc. Pet. Geol. 14, 1989, pp. 449-468.

8. Klapper G., Uyeno T. T., Armstrong D. K., Telford P. G. Conodonts of the Williams Island and Long Rapids Formations (Upper Devonian, Frasnian-Famennian) of the Onakawana B Drillhole, Moose River basin, northern Ontario, with a revision of Lower Famennian species. Journal of Paleontology 78(2), 2004, pp. 371-387.

9. Klapper G. Frasnian (Upper Devonian) conodont succession at Horse Spring and correlative sections, Canning Basin, Western Australia. Journal of Paleontology 81(3), 2007, pp. 513-537.

10. Klapper G. Feist R., Becker R. T., House M., R. Definition of the Frasnian/Famennian Stage boundary. Episodes, 16 (4), 1993, pp. 433-441.

11. Marshall J. E. A., Telnova O. P., Vetoshkina O. S. Ecosystem Crisis at the Frasnian-Famennian Boundary (Southern Timan). Doklady Earth Sciences, 440, 2011, pp. 1396-1398.

12. Racki G. Towards understanding Late Devonian global events: few answers, many questions. Over D. J., Morrow J. R., Wignall P. B. (Eds.). Understanding Late Devonian and PermianTriassic Biotic and Climatic Events. Towards an Integrated Approach. Development in Palaeontology \& Stratigraphy, 20, 2005, pp. 5-36.
13. Racki G., Racka M., Matyja H., Devleeschouwer X. The Frasnian/Famennian boundary interval in the South PolishMoravian shelf basins: integrated event-stratigraphical approach. Palaeogeogr., Palaeoclimatol., Palaeoecol., 2002, V. 181, pp. 251-297.

14. Sandberg C. A., Morrow J. R., Ziegler W. Late Devonian sea-level changes, catastrophic events, and mass extinctions. Catastrophic Events and Mass Extinctions: Impacts and Beyond. Geol. Soc. Amer. Spec. Pap., 356, 2002, pp. 473-487.

15. Soboleva M. A. Konodontovyye biofatsii v razreze franskogo yarusa na r. Kozhym (Pripolyarnyy Ural) (Conodont biofacies in Frasnian stage on Kozhim River (Subpolar Urals). Struktura, veshchestvo, istoriya litosfery Timano-Severoural'skogo segmenta: Proceedings of conference. Syktyvkar, 2016, pp. 171-175.

16. Soboleva M. A., Sobolev D. B. New data on conodonts of Upper Devonian of the Polar Urals (Ostantsovyi section, Malaya Usa River). Uchenye zapiski Kazan'Univ. Ser. Estestvennye nauki, 2016, 158 (3), pp. 455-467.

17. Soboleva M. A. Rol' biofatsial'nogo analiza dlya ustanovleniya transgressivno-regressivnykh tsiklov $i$ global'nykh sobytiy (na primere razreza franskogo yarusa $r$. Kos'yu) (Role of biofacies analysis for establishing transgressive-regressive cycles and global events (Frasnian at Kosyu River)). Struktura, veshchestvo, istoriya litosfery Timano-Severoural'skogo segmenta: proceedings of conference. Syktyvkar, 2017, pp. 210-221.

18. Soboleva M. A., Sobolev D. B., Matveeva N. A. Frasnian section on the Kozhym River (the western slope of Polar Urals) results of biostratigraphic, bio- and lithofacies, isotopic and geochemical studies. Neftegazovaya Geologiya. Teoriya I Praktika, 2018, 13 (1). available at: http://www.ngtp.ru/rub/2/2_2018.pdf

19. Spalletta C., Perri M. C., Over D. J., Corradini C. Famennian (Upper Devonian) conodont zonation: revised global standard. Bulletin of Geosciences, 92(1), 2017, pp. 31-57.

20. Walliser O. H. Global events in the Devonian and Carboniferous. O. H. Walliser (Ed.). Global Events and Event Stratigraphy in the Phanerozoic. Berlin: Springer, 1996, pp. 225-250.

21. Yudina A. B., Racki G., Savage N. M., Racka M., Maikowski K. The Frasnian-Famennian events in a deep-shelf succession, Subpolar Urals: biotic, depositional and geochemical records. Acta Palaeontologica Polonica, 47(2), 2002, pp. 355-372.

22. Ziegler W., Sandberg C. A. The Late Devonian standard conodont zonation. Courier Forschungs institute Senkenberg, $121,1990,115 \mathrm{p}$. 